\title{
The most important things I have learnt in practice, advice for social work students
}

\author{
Kerri Cleaver (Kāi Tahu, Kāti Māmoe, Waitaha), University of Otago, Aotearoa New Zealand
}

I accidentally came across social work. I'd been living up North doing craft design and then got pregnant with my oldest daughter, so we moved down to Dunedin. I was waiting for the weaving course to start at the University of Otago, however it took a few years to get under way. Eventually I was pregnant again and the course still hadn't started, so I thought I would try some social work papers. I was hapu for the first couple of weeks and then carrying the baby for the next year to all my classes and everyone was so supportive.

Even though I didn't end up doing the weaving course, art has been a part of my social work. One of the things to be careful of, is that I started to lose it in the years of working in white agencies. There is value in what you take with you and art for me has always been part of that, as has doing weaving with whānau, but it has really been for my own self-care. It's good not always being in a place where we're dominated by our thinking and our working, but having something for yourself as well. For me, being connected to those things that strengthen my being Māori are an important part of my self-care.

When I took a break from front-line social work in 2016, it was because I was burnt out. I'd done just over 10 years-and probably did about four months too much. I had planned my exit and didn't do my best practice over those last four months, so I think one of the things I've learnt is that you should recognise when you need to take a break. I didn't completely take a break; I did lots of things in the community, but it is different than working in a full-time job and looking after other peoples' needs.
That wasn't the part of the job that I found really hard, the part I found really hard was institutional constraint, whether in the institution itself or the agencies I worked with. That dynamic was what really, in the end, made me need a break.

Reflecting on my journey as a social worker, I would not say when I started working that I was a Māori social worker. I would say that I was a social worker who was Māori. I think I found it complicated by the "Are you Māori enough?" question, but for me, some of the things I did in practice were not based solely in tikanga and kawa, so I didn't want to own that space of being a "Māori social worker." However, I was a social worker who was Māori and brought special skills into that role. But, through my journey, I now know that I am a Māori social worker and I think I probably always was. It just took me a while to grow into knowing that. I think I might have always been a social worker too, as being a social worker isn't something that only applies during work hours, it's just something in my life.

Until 2020 I had only worked in Pākehā organisations. I worked at Oranga Tamariki and then as a social worker in schools for the Anglican Family Care, followed by some contracting work for ACC through Delta Psychology - so all of those roles were really in Pākehā organisations. I think it takes its toll on you as a Māori social worker. When I went for a job at Child Youth and Family, Oranga Tamariki, I rang up this colleague, a Māori person and said "Can we have a chat?" I asked "Is this going to be safe? Is it going to be safe to work here?" and she was like "Yes, absolutelyit's totally going to be safe to work here." 
"Is this going to be whānau friendly?" because I had three young children by that stage ... and it was like "Yeah, no-I've got children. It's totally all good to work here as a parent" ... and it really wasn't. And then she jumped ship!

So, interview your agencies, back yourselves, because you are Māori social workers-that's special and that's something our Pākehā colleagues don't have. They don't have the lived experiences of being Māori. And it doesn't matter what that lived experience is, it really doesn't matter how that's lived out, it doesn't matter if you are at the start of your journey of finding out your whakapapa and finding out your connections. That is something that you are dealing with and carrying, and that is a lived experience of being Māori. It is something that other people can't understand, but that you do and that is special when working with many whānau because they are often dealing with those same issues. So when you go into job interviews, back yourself and know that you can talk to that. That it is real knowledge that you carry. Take some time to reflect on how you might present that in an interview process. I know that if you're going to go work in a Māori agency, they are already going to understand that. They know what strength you bring. But if you're going to go and work for a Pākehā organisation like Oranga Tamariki they often don't 'get' that. Some of them do, but generally they really don't.

I have to say we are in changing times and one of the things is knowing who to ally with, and also knowing that you don't have to. Just ally with the people that you know want to do the good work - and there are people out there who are willing to do the good work. Don't just waste your time on people trying to convince them to see it your way-they're never going to see it your way, so you're just wasting your energy. I'm not suggesting that you don't try to have those conversations, but if they're not working, then move on.
I've been on interview panels and it's been an amazing experience. Especially when Pākehā listen to you. Usually when you are on an interview panel, you are the only Māori and because "they" don't get that there should be more than a token Māori, you will have to explain what they are getting from a Māori social worker that they might not get from someone else. You need to be able to understand that strength for yourself, going into that interview, what that looks like for you and how to talk that up.

When you go into those interviews, interview the agencies and see if they're going to be a 'good fit' and be willing to leave if they're not. Also, don't hold on to the ties of agencies that don't look after you. Just jump ship and get another job. Grow: take the time to grow your roles in the community. I had already started that process before I had fully trained as a social worker. It started with the first social work paper that I did, when I said to myself, "I'm not doing enough in my community." So I started going to the marae and helping out in the kitchen and doing Kotahi Mano Kaika-I'm still really terrible with my reo, I think I am worse now at my language than I was back then! (I don't know how that happened). It is important to build those connections in the community. I think it's so much harder to maintain those connections if you're in a job for 40 hours a week. That is why it is important to work for an agency that supports those relationships. But if you're not in an agency that supports that then that becomes difficult.

Do your research. Do as much research as possible before you go into an interview: you need to know what the job is. You also need to know what the other things that the agency does are. We look for that when we're on the panel.

In your examples-and again this is specifically if you've got a panel of nonMāori interviewing you-you're going to have to be explicit about the things 
that you do as Māori, because they're generally not going to pick up on that otherwise. The things that you might take for granted, especially regarding ways of working, you might actually have to voice so that it is understood. You might have to explain a Māori model and as you're talking through it, translate it. When taking about building relationships, "Oh, that's whakawhanaungatanga" ... just pop it in so that they go "Oh, right-they' re working in a Māori way." It's common knowledge to us. It may not be not common knowledge outside of us.

Finally, when you're out there going for jobs: you are the sweetest kumara, so back yourself. 